\title{
Streamside Management Zone (SMZ) EFficiency in HeRbicide Retention From Simulated SuRface Flow ${ }^{1}$
}

\author{
Eficiência de Zonas Ripárias (SMZ) na Retenção de Herbicidas Presentes em Escoamento \\ Superficial Simulado
}

\author{
MATOS, A.T. ${ }^{2}$, PINHO, A.P. ${ }^{3}$, COSTA, L.M. ${ }^{4}$ e MORRIS, L.A. ${ }^{5}$
}

\begin{abstract}
Plot-scale overland flow experiments were conducted to evaluate the efficiency of streamside management zones (SMZs) in retaining herbicides in runoff generated from silvicultural activities. Herbicide retention was evaluated for five different slopes (2, 5, 10, 15, and 20\%), two cover conditions (undisturbed $O$ horizon and raked surface), and two periods under contrasting soil moisture conditions (summer dry and winter wet season) and correlated to $O$ horizon and site conditions. Picloram (highly soluble in water) and atrazine (moderately sorbed into soil particles) at concentrations in the range of 55 and $35 \mu \mathrm{g} \mathrm{L}^{-1}$ and kaolin clay (approximately $5 \mathrm{~g} \mathrm{~L}^{-1}$ ) were mixed with 13.000 liters of water and dispersed over the top of $5 \times 10 \mathrm{~m}$ forested plots. Surface flow was collected 2, 4, 6, and $10 \mathrm{~m}$ below the disperser to evaluate the changes in concentration as it moved through the $O$ horizon and surface soil horizon-mixing zone. Results showed that, on average, a $10 \mathrm{~m}$ long forested $S M Z$ removed around $25 \%$ of the initial concentration of atrazine and was generally ineffective in reducing the more soluble picloram. Retention of picloram was only $6 \%$ of the applied quantity. Percentages of mass reduction by infiltration were $36 \%$ for atrazine and $20 \%$ for picloram. Stronger relationships existed between $O$ horizon depth and atrazine retention than in any other measured variable, suggesting that better solid-solution contact associated with flow through deeper $O$ horizons is more important than either velocity or soil moisture as a determinant of sorption.
\end{abstract}

Keywords: pollution control, silviculture, pesticides, runoff.

\begin{abstract}
RESUMO - Experimento de escoamento superficial, em escala piloto, foi conduzido para se avaliar a eficiência de zonas ripárias (SMZs) na retenção de herbicidas presentes no escoamento superficial gerado em atividades silviculturais. A retenção do herbicida foi avaliada em terrenos com cinco diferentes declividades (2, 5, 10, 15 e 20\%), duas condições de cobertura do solo (com e sem o horizonte $\mathrm{O}$ ) e dois periodos de distintos teores de água no solo (verão seco e inverno úmido). Picloram (altamente solúvel em água) e atrazina (moderadamente adsorvivel às partículas de solo), em concentrações na faixa de 55 e $35 \mu \mathrm{g} \mathrm{L}{ }^{1}$, e caulinita (aproximadamente $5 \mathrm{~g} \mathrm{~L}^{-1}$ ) foram misturados com 13.000 litros de água e aplicados sobre o solo de áreas experimentais florestadas de $5 \times 10 \mathrm{~m}$. O escoamento superficial foi coletado a 2, 4, 6 e $10 \mathrm{~m}$ abaixo do ponto de aplicação, para que se pudesse avaliar as mudanças nas concentrações dos contaminantes na suspensão em escoamento. Resultados mostraram que, em média, faixas de $10 \mathrm{~m}$ de comprimento de SMZ florestada foram capazes de proporcionar remoção em torno de $25 \%$ na concentração inicial de atrazina e foram, geralmente, ineficientes na remoção de picloram, sendo essa remoção de apenas $6 \%$ do total aplicado. As reduções percentuais de massa, com a infiltração da suspensão no solo, foram de $36 \%$ apara a atrazina e $20 \%$ para o picloram. Existe forte relação entre profundidade
\end{abstract}

Recebido para publicação em 18.10.2006 e na forma revisada em 4.1.2008.

Professor, Agricultural Engineering Department, Universidade Federal de Viçosa, Viçosa, MG, 36.571-000, <atmatos@ufv.br>;

${ }^{3}$ D.Sc. in Agricultural Engineering, Agricultural Engineering Department, Universidade Federal de Viçosa; ${ }^{4}$ Professor, Soil Department, Universidade Federal de Viçosa, <liovando@solos.ufv.br>; ${ }^{5}$ Professor, School of Forestry Resources, University of Georgia, Athens, GA, EUA.

Planta Daninha, Viçosa-MG, v. 26, n. 1, p. 131-142, 2008 
do horizonte $\mathrm{O}$ e retenção de atrazina e isso sugere que maior contato sólido-solução associado com baixas velocidades de percolação, em mais profundos horizontes, são fatores de maior influência na sorção do herbicida do que o teor de água no solo e a inclinação do terreno.

Palavras-chave: controle da poluição, silvicultura, pesticidas, escoamento superficial.

\section{INTRODUCTION}

Pine plantation establishment in the US South and elsewhere involves intensive site preparation, including mechanical soil disturbance (disk harrowing, sub soiling, or bedding) fertilization, and application of one or more herbicides for competition control during the first few years following planting. Commonly used herbicides exhibit a range of soil sorption characteristics and mobility, resulting in different fates within the ecosystem. Herbicides with high sorption and hydrophobic characteristics tend to have higher persistence in soils, while those with low sorption and hydrophilic characteristics have higher mobility rates (Mersie et al., 1999). Herbicides can be transported in soluble form or bound to suspended colloidal-sized particles. Dissolved forms tend to reach the surface water more easily, while bound forms tend to be retained in the soil. Both can be a significant source of surface water pollution, particularly when a rain event of high intensity occurs right after application (Koppel et al., 1997). Generally, only 1 to $10 \%$ of the herbicide applied is lost in runoff (Vellidis et al., 1994), but this amount still can be harmful to the aquatic ecosystem. In particular, recent studies of herptofauna in the US South have found that low concentrations of atrazine in surface waters can interfere in the reproduction behavior (Allran and Karasov, 2001; Dalton, 2002; Hayes et al., 2002).

In the US, voluntary Best Management Practices have been developed and adopted by the agricultural and forest industries as a means of protecting water quality. One of the most widely adopted and successful Best Management Practices is the establishment of Streamside Management Zones (SMZs). Streamside management zones are 10 to $50 \mathrm{~m}$ wide strips of land adjacent to surface waters within which silvicultural operations are limited and site disturbance is minimized. The potential removal mechanisms associated with these streamside management zones for pollutants in runoff involve changes in flow hydraulics that enhance the opportunity for infiltration of runoff water, deposition of sediment, filtration of suspended sediment by vegetation, pollutant adsorption onto in-place soil and dead and living plant surfaces, and adsorption of soluble pollutants by plants (NCASI, 1992). Streamside Management Zones have been shown to be effective in preventing silt- and sand-sized sediment and nutrients from reaching streams (Lowrance, 1998; Rivenbark, 2002).

Significant surface water protection may be achieved by filtration of colloidal material in O horizon, litter layer and organic matterrich surface horizons. Herbicides adsorbed into soil particles are trapped in SMZs as runoff water slows and sediments are deposited. Additionally, herbicides in the aqueous phase of runoff can be retained through infiltration and adsorption. According to Webster and Shaw (1996), the addition of a grass streamside filter strip reduced the quantity of atrazine in runoff from soybean by $30 \%$. Mersie et al. (1999) observed that switchgrass filter strips reduced the mass of dissolved atrazine and metolachlor from applied run-on by $52 \%$ and $59 \%$, respectively. Significant improvements over $41 \%$ and $44 \%$ reductions were observed for bare soils. In one of the few studies of herbicide retention in forested streamside management zones, Vellidis et al. (2002) studied the effects grass, natural forest and 2-year-old planted pine streamside filter strips exert on retention of alachlor and atrazine in surface runoff from 4 naturally occurring storm events in the Coastal Plain of Georgia. In grass, the average reduction in atrazine concentration $\left(\mu \mathrm{g} \mathrm{L}^{-1}\right)$ when adjusted for dilution was $6.0 \%$ per meter 
of buffer strip. In natural forest and planted pine, dilution adjusted runoff concentrations were reduced, on average, by $2.5 \%$ and $4.4 \%$, respectively.

As demonstrated by Aora et al (1996), Vellidis et al. (2002) and others, trapping efficiency in SMZ is dependent on a number of factors including herbicide characteristics such as soil sorption and half-life, and SMZ characteristics such as slope, length and width, soil moisture, timing of rainfall events and rainfall intensity, and vegetation. Most previous work has focused on grass filter strips and little information is available that can be used to predict retention of herbicides within forested SMZs.

The objectives of this research were to: (1) quantify removal of dissolved herbicides in forested streamside management zones of different slope and antecedent moisture conditions, (2) evaluate the relative role of the undisturbed floor on retention by comparing results from undisturbed plots to results from O horizon removal plots, (3) evaluate the relative importance of several site factors in predicting herbicide sorption.

\section{MATERIAL AND METHODS}

To evaluate forested SMZ efficiency in retaining herbicides, plot scale overland flow experiments were conducted using atrazine and picloram, two typical silvicultural herbicides. Atrazine is a selective triazine herbicide used to control broadleaf and grassy weeds. Although it tends to bind to soil particles; its movement to surface and groundwater is well known (Paterson and Schoonor, 1992). Picloram is poorly sorbed to soil particles and therefore can be easily transported to surface water through runoff. Picloram, a systemic herbicide used for control of woody plants and a wide range of broad- leaved weeds, has been intensively used in forestry. Although atrazine has been intensively studied, its retention in SMZ through runoff is poorly understood. The chemical properties and behavior of these herbicides in the environment are presented in Table 1.

Experimental plots were installed within forested Streamside Management Zones (SMZs) established along streams adjacent to pine plantations located in the Oconee River watershed, in Clarke, Putnam and Jasper Counties in the Piedmont of northeastern Georgia. Five sites were selected to represent five slope classes $(1-2 \%, 5-7 \%, 10-12 \%, 15-17 \%$ and $20-22 \%$ ) and the range of conditions characteristic of Piedmont SMZs (Table 2). Vegetation species within all but the 1-2\% slope were dominated by mature stands of mixed oaks that had a duff mull (moder) type O horizon (Oi and Oe horizons present) over Typic Kanhapludult mineral soils. The 1-2\% slope class site was within the alluvial floodplain and was characterized by sycamore, sweetgum and elm occurring on Fluvaquent with a mull humus type (Oi horizon only). These conditions are also typical of conditions occurring on similar landscape position in the Piedmont. Mean $\mathrm{O}$ horizon thickness ranged from a low of $1.3 \mathrm{~cm}$ on the $1-2 \%$ slope class to $8.3 \mathrm{~cm}$ on the $15-17 \%$ slope class.

Two 5 x 10 m experimental plots (Figure 1) were installed with the $5-7 \%, 10-12 \%$ and $15-$ $17 \%$ slope classes. One $5 \mathrm{~m}$ x $10 \mathrm{~m}$ experimental plot was installed within the 1$2 \%$ and $20-22 \%$ slope class sites. Each plot was installed with the $5 \mathrm{~m}$ side oriented to the upper edge of the $\mathrm{SMZ}$ and extending $10 \mathrm{~m}$ into the SMZ on an area with a near planer slope and where no large downed trees, obvious stumps or other disturbance occurred. Surface flow collectors as described by Franklin et al. (2001) were installed on each plot 2, 4, 6 and

Table 1 - Selected chemical properties of atrazine and picloram related to soil mobility ${ }^{1 /}$

\begin{tabular}{|c|c|c|c|c|c|}
\hline Pesticide & $\mathrm{Kd}^{*}$ & $\begin{array}{c}\text { Koc** } \\
\left(\mathrm{L} \mathrm{kg}^{-1}\right)\end{array}$ & $\begin{array}{c}\text { Solubility in water } \\
\left(\mathrm{mg} \mathrm{L}^{-1}\right)\end{array}$ & $\begin{array}{c}\text { Relative } \\
\text { adsorption }\end{array}$ & Relative mobility \\
\hline Atrazine & 2.46 & 100 & 30 & High & Low \\
\hline Picloram & NA*** & 16 & 430 & Low & High \\
\hline
\end{tabular}

$\stackrel{1}{1}$ Source: USDA. * Sorption coefficient in presence of clay. ** Organic-carbon partition coefficient. *** Not available. 
Table 2 - Characteristics of SMZs from which intact O horizon samples were collected for laboratory adsorption study

\begin{tabular}{|c|c|c|c|c|c|}
\hline Site & Location & $\begin{array}{l}\text { Slope range } \\
(\%)\end{array}$ & Dominant overstory species & $\begin{array}{c}\text { Age of } \\
\text { dominant trees } \\
(\mathrm{yrs})\end{array}$ & $\begin{array}{l}\text { O horizon } \\
\text { thickness }(\mathrm{cm})\end{array}$ \\
\hline 1 & Jasper & $1-2$ & $\begin{array}{l}\text { Sycamore (Plantanus occidentalis) } \\
\text { Sweetgum (Liquidambar styraciflua) } \\
\text { Winged elm (Ulnus alata) }\end{array}$ & 45 & $1.3 \pm 1.5$ \\
\hline 2 & Putnam & $5-7$ & $\begin{array}{l}\text { Northern red oak (Quercus rubra) } \\
\text { Southern red oak (Quercus falcata) } \\
\text { Mockernut hickory (Carya tomentosa) } \\
\text { Pignut hickory (Carya glabra) } \\
\text { Sweetgum (Liquidambar styracifua) }\end{array}$ & 75 & $2.3 \pm 0.8$ \\
\hline 3 & Clarke & $10-12$ & $\begin{array}{l}\text { Southern red oak (Quercus falcata) } \\
\text { Sweetgum (Liquidambar styraciflua) }\end{array}$ & 55 & $2.7 \pm 1.9$ \\
\hline 4 & Putnam & $15-17$ & $\begin{array}{l}\text { Northern red oak (Quercus rubra) } \\
\text { Southern red oak (Quercus falcata) } \\
\text { Mockernut hickory (Carya tomentosa) } \\
\text { Pignut hickory (Carya glabra) } \\
\text { Sweetgum (Liquidambar styracifua) }\end{array}$ & 90 & $8.3 \pm 2.9$ \\
\hline 5 & Putnam & $20-22$ & $\begin{array}{l}\text { Northern red oak (Quercus rubra) } \\
\text { Southern red oak (Quercus falcata) } \\
\text { Mockernut hickory (Carya tomentosa) } \\
\text { Pignut hickory (Carya glabra) } \\
\text { Sweetgum (Liquidambar styracifua) }\end{array}$ & 60 & $6.5 \pm 2.3$ \\
\hline
\end{tabular}

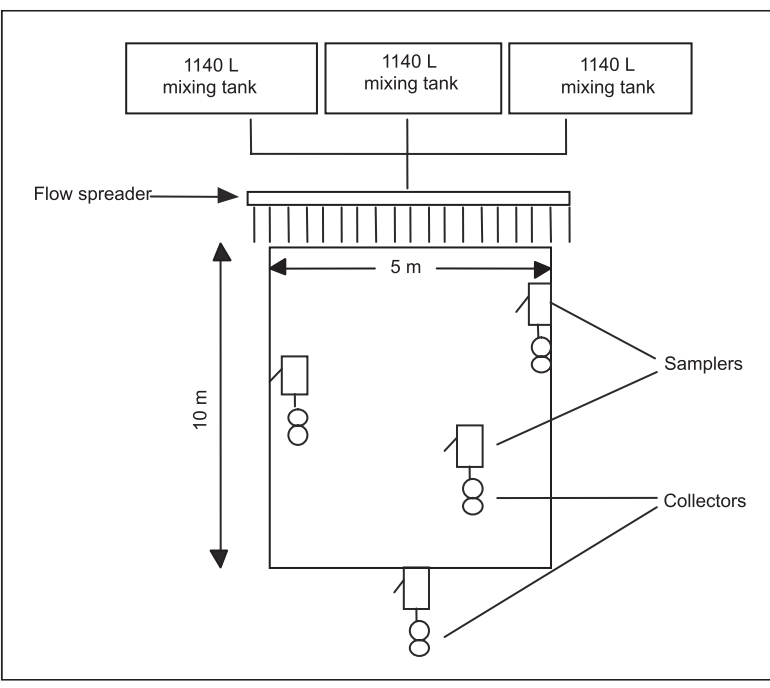

Figure 1 - Design of the experimental plots, distribution and sampling system of surface flow mixture.

$10 \mathrm{~m}$ from the upslope edge. These samplers had outlets for sampling $1 / 10$ of the flow (used for low flows) and $1 / 100$ of the flow (used for high flows). To install samplers, $5 \mathrm{~cm}$ diameter holes were bored with a bucket auger, steel screw rods set into the holes and the holes filled with soil and capped with cement. Collectors were placed onto the rods and adjusted and leveled using standard wing nuts. Sample collectors were placed immediately behind each surface collector by excavating a hole with a post-hole digger and placing a $20 \mathrm{~cm}$ diameter capped PVC pipe within the hole. Holes were cut through these retaining pipes to provide access to a $15 \mathrm{~cm}$ diameter $\mathrm{x}$ $45 \mathrm{~cm}$ long sample collectors, also constructed of PVC, which were placed within each retaining pipe. These samplers were connected to the appropriate $1 / 10$ or $1 / 100$ sample split outlet port of the connectors with PVC pipe.

Each plot was instrumented with 24 sets of TDR (time domain reflectometry) rods. Rod pairs were installed vertically to $30 \mathrm{~cm}$ depth and $60 \mathrm{~cm}$ depth within and surrounding each plot. Rods within the plot were placed $1.5 \mathrm{~m}$ from the plot edge at $0,2,5$, and 10 from the upslope edge of the plot. Additionally, TDR rod sets were set $1 \mathrm{~m}$ and $4 \mathrm{~m}$ outside the plot at $2,5,10,12$ and $14 \mathrm{~m}$ from the upper plot edge and below the plot at 12 and $14 \mathrm{~m}$ from the upper edge of the plot. For purposes of characterizing surface soil conditions, two additional sets of TDR rods were installed within the plot from 0 to $10 \mathrm{~cm}$ depth 0,5 and $10 \mathrm{~m}$ from the upper edge of the plotThe 
equipment was previously used by Noborio (2001).

Prior to the first simulation run, surface cover type was classified as (leaf litter, branch litter $(<4 \mathrm{~cm}$ diameter) or coarse wood $(>4 \mathrm{~cm}$ diameter) or bare soil) using a diagonal transect across the plot, with measurements at $10 \mathrm{~cm}$ intervals. These data are included in Appendix A. Where an O horizon was present, the depth to mineral soil was recorded to 0.1 $\mathrm{cm}$. Additionally, overstory and understory basal area was measured and recorded by species and age of two dominant trees on or immediately adjacent to the experimental plots determined by increment coring. Soil profiles were described near the plot and the depth to the top of the Bhorizon recorded.

Prior to simulation runs using the herbicide and kaolin mix, a water-only run was accomplished on one plot per slope class to establish background kaolin and herbicide concentrations. Analyses of these samples indicated very low background concentrations and/or analytical interference (kaolin = $0.29 \mathrm{~g} \mathrm{~L}^{-1}$, atrazine $=0.50 \mu \mathrm{g} \mathrm{L}^{-1}$, picloram $=$ $0.38 \mu \mathrm{g} \mathrm{L}^{-1}$ ) in runoff from the sites.

Surface flow was simulated by applying a mixture of unwashed kaolin clay, and the two herbicides to the upslope edge of the upper edge of the $5 \mathrm{~m}$ (wide) $\times 10 \mathrm{~m}$ (depth) plots using a $5 \mathrm{~m}$ wide dispersing system, similar to one described by McCutcheon et al. (2000). The surface flow mixture concentration was formulated on the basis of expected concentrations and content of runoff associated with a rainfall event with a return frequency of one year occurring immediately after pesticide application. Atrazine and picloram concentrations were 55 and $35 \mu \mathrm{g} \mathrm{L}{ }^{-1}$, respectively. In addition, commercial mine kaolin was added to the mixture so that the final concentration in applied surface flow would be $5.0 \mathrm{~g} \mathrm{~L}^{-1}$. The kaolin used was unwashed and, consequently, contained some surface coating of iron oxides that provided some surface adsorption. The kaolin was not dispersed before addition and the resulting mixture contained both colloidal sized clay and small aggregates. The Soil Conservation Service Curve Number Method was used to calculate the total surface flow volume (around $13,000 \mathrm{~L}$ ) produced in a clear-cut area of
$1600 \mathrm{~m}^{2}$, with a high intensity rainfall event of $50 \mathrm{~mm} \mathrm{~h}^{-1}$, and return period of 1 year. These values were based, in part, on results of Rivenbark (2002) survey of upslope conditions leading to $\mathrm{SMZ}$ concentration areas and breakthrough occurrence on commercially harvested and regenerated sites in the Georgia Piedmont. To prepare the mixtures, concentrated mixes were prepared in $20 \mathrm{~L}$ buckets the day before (approximately 20 hours) each run. Three 1140 L tanks were used to mix the prepared concentrated mixtures with clean water pumped from local wells and delivered to the site in a tanker truck. The concentrated mix and water was mixed in the tanks approximately 10 minutes before being applied to the site. A near constant surface flow volume was simulated by sequentially emptying the mixing tanks and using a hand adjusted flow valve to adjust flow rates so that each mixing tank emptied over a 5.5 minute time interval. In practice, flow rates were greater when a new tank was started because of greater hydraulic head. Generally, simulation runs were completed in about 70 minutes.

Beginning approximately 1 hour prior to each simulation run and concluding just prior to each run, readings were taken on all TDR sets to determine initial soil water content. TDR readings were taken again, beginning on the upslope edge of the plot about 15 minutes before the end of the run and concluding within about 10 minutes after the end of the run. Concomitant with TDR measurement, soil temperature was measured at $10 \mathrm{~cm}$ depth using a dial thermometer 0,5 and $10 \mathrm{~m}$ from the upslope edge of the plot.

Both the velocity of surface flow running through the plot and the proportion of the plot over which surface runoff occurred was measured during the last 15 minutes of each simulation run. Velocity was measured by introducing dye and measuring travel time through a measured $1 \mathrm{~m}$ length within the following intervals: 1-2, 4-5, 6-7 and 9-10 below the upslope edge of the plot. To determine proportion of the plot over which surface flow occurred, transects were established across the width of the plot $2 \mathrm{~m}, 4 \mathrm{~m}, 6 \mathrm{~m}$ and $10 \mathrm{~m}$ from the upslope plot edge and flow and noflow conditions recorded along each transect. 
Surface flow volume was determined by removing previously tarred collectors from either the $1 / 10$ or $1 / 100$ sample split and weighing the accumulated surface flow whenever the collector filled.

To determine actual application rates, a sample of the mixture was collected from the distributor during the first third, middle third and last third of each run. Surface flow collectors were similarly subsampled for herbicide concentrations during the first third, middle third and last third of each run. These samples were stored in glass vials and returned to the laboratory where they were stored at $4{ }^{\circ} \mathrm{C}$ until analyzed.

Within 24 hours after being returned to the laboratory, a well-mixed $40 \mathrm{~mL}$ subsample was centrifuged and two duplicate samples of the supernatant solution were removed and stored for analysis. Herbicide determination was made by enzyme-linked immunoassay (ELISA test) produced by Strategic Diagnostics Inc., Newark Delaware, with detection range of 0.04 to $5.0 \mu \mathrm{g} \mathrm{kg}^{-1}$ for atrazine and 0.87 to $20 \mu \mathrm{g} \mathrm{kg}^{-1}$ for picloram. These analyses were carried out at the University of Georgia Pesticide and Hazardous Waste Laboratory. All analyses were completed in duplicate with appropriate standards and quality assurance/ quality control protocols (QA/QC) followed.

There was no pattern in herbicide concentration among the three collection times within each sample run and evaluations were based on mean concentrations of individual collection locations. To test the overall effect of season on surface soil moisture content, a t-test was run across all slope classes and $\mathrm{O}$ horizon disturbance by season $(p=0.0016)$. As this test indicated significant differences, moisture content was retained as a site variable and the two sample runs completed on each site were treated individually in subsequent analyses.

The inflow concentration remaining on the $\mathrm{SMZ}$ or infiltrating, is the trapping efficiency:

$$
T E=\frac{C i-C o}{C i} 100
$$

where TE is the trapping efficiency of the SMZ, $\mathrm{C} i$ is the concentration entering the $\mathrm{SMZ}$, and
Co is the concentration leaving the $\mathrm{SMZ}$ (McCutcheon et al., 2000).

Overall correlations among variables were tested through Pearson correlation coefficients using the Statistical Analysis System (SAS). Linear regressions were used to establish relationships between herbicide attenuation and distance within the SMZ.

\section{RESULTS AND DISCUSSION}

The degree which herbicides and other contaminants are retained in the SMZs depends on a variety of factors. The most important among these is the actual flow path through the SMZ. Dispersed "sheet flow" will tend to have lower velocities and greater contact with surfaces than concentrated flows both of which should increase retention of contaminants. However, sediment filtration remains significant even concentrated flow zones within the SMZs (Ward, 2001). The surface flow that was evenly distributed across the upper edge of the experimental plots tended to concentrate as it moved through the $\mathrm{SMZ}$ as a result of microtopographic variation even though care was taken to select experimental plots that were uniform in appearance. For most of the runs the surface flow was reduced from $100 \%$ at the distributor to $90 \%$ at the $2 \mathrm{~m}$ transect. On average, surface flow occurred across only $62 \%$ at the lower edge of the $10 \mathrm{~m}$ long plot (Table 3). This concentration had two important effects. First, it increased flow velocity by increasing flow depth and likely reduced herbicide retention within the SMZ. Second, it contributed to high variability in measured surface flow volume. The average of the surface flow path width at the lower edge of the plot was 53 and $63 \%$, respectively for the plots with and without $\mathrm{O}$ horizon, and 58 and $65 \%$ for summer and winter season, respectively.

Samplers were installed systematically within the experimental plot, some samplers collected little or no surface flow and others, that happened to be installed in a concentrated flow zone, collected surface flow that represented more than the actual width of the plot they sampled. 
Table 3 - Concentration of surface flow within $10 \mathrm{~m}$ long plots within SMZs of various slopes

\begin{tabular}{|c|c|c|c|c|c|c|c|c|c|}
\hline \multicolumn{10}{|c|}{ Slope $\mathrm{x}$ lasses } \\
\hline & $\begin{array}{c}\text { Distance } \\
(\mathrm{m})\end{array}$ & $\begin{array}{c}2 \% \\
\text { WOH }\end{array}$ & $\begin{array}{c}5 \% \\
\text { WOH }\end{array}$ & $\begin{array}{c}5 \% \\
\text { WOOH }\end{array}$ & $\begin{array}{c}10 \% \\
\text { WOH }\end{array}$ & $\begin{array}{c}10 \% \\
\text { WOOH }\end{array}$ & $\begin{array}{l}15 \% \\
\text { WOH }\end{array}$ & $\begin{array}{c}15 \% \\
\text { WOOH }\end{array}$ & $\begin{array}{l}20 \% \\
\text { WHO }\end{array}$ \\
\hline \multicolumn{10}{|c|}{ Surface flow path width (\% of the initial width) } \\
\hline \multirow{5}{*}{ Summer } & 0 & 100 & 100 & 100 & 100 & 100 & 100 & 100 & 100 \\
\hline & 2 & 96 & 94 & 92 & 72 & 98 & 114 & 108 & 36 \\
\hline & 4 & 110 & 92 & 78 & 80 & 106 & 94 & 100 & 52 \\
\hline & 6 & 56 & 112 & 64 & 14 & 64 & 72 & 104 & 50 \\
\hline & 10 & 0 & 40 & 86 & 0 & 44 & 46 & 66 & 68 \\
\hline \multirow{5}{*}{ Winter } & 0 & 100 & 100 & 100 & 100 & 100 & 100 & 100 & 100 \\
\hline & 2 & 90 & 100 & 80 & 84 & 94 & 98 & 92 & 80 \\
\hline & 4 & 124 & 88 & 50 & 94 & 98 & 78 & 92 & 62 \\
\hline & 6 & 128 & 74 & 68 & 118 & 94 & 66 & 98 & 76 \\
\hline & 10 & 0 & 36 & 54 & 120 & 54 & 58 & 76 & 58 \\
\hline
\end{tabular}

$* \mathrm{WOH}=$ with $\mathrm{O}$ horizon, $\mathrm{WOOH}=$ without $\mathrm{O}$ horizon

Conditions of each surface flow simulation are presented in Table 4. During the first two simulation runs on the $10-12 \%$ slope in Clarke County $(21 / 09 / 01$ and $11 / 10 / 01)$ target concentrations of atrazine and picloram of $550 \mu \mathrm{g} \mathrm{L}^{-1}$ and $350 \mu \mathrm{g} \mathrm{L}^{-1}$, respectively, were applied to the plots. Once it was determined that concentrations of surface flow sampled in the last collector (10 $\mathrm{m}$ sampling location) were well within the analytical detection range, target concentrations were reduced to 55 and $35 \mu \mathrm{g} \mathrm{L}^{-1}$ of atrazine and picloram, respectively. Actual (measured) mixture concentrations ranged from 49 to $114 \mu \mathrm{g} \mathrm{L}^{-1}$ atrazine and 32 to $58 \mu \mathrm{g} \mathrm{L}^{-1}$ picloram. Lower-than-target concentrations of herbicides in simulations were not unexpected as sorption to clay in the mix occurred. Excluding the preliminary wateronly simulation runs, mean application rate varied from 144 to $213 \mathrm{~L} \mathrm{~min}^{-1}$ with an average of $178 \mathrm{~L} \mathrm{~min}^{-1}$ across all simulations. Initial surface soil moisture content varied from a low of $15 \%$ to a high of almost $40 \%$, the latter occurring on simulation run begun shortly after a significant summer precipitation event.

Because of the high variability in surface water collection, the mass of water retained within the soil profile was calculated using the measured volumetric soil water content change with depth. This soil storage volume was subtracted from the total volume of surface flow applied and the residual volume multiplied by the observed concentration at the $10 \mathrm{~m}$ collectors to determine mass herbicide retention.

Observed reductions in concentration and mass within the $10 \mathrm{~m} \mathrm{SMZ}$ are presented for each run and for all runs combined in Table 5 . A significant reduction in herbicide concentration within the SMZ was only observed for atrazine. The overall atrazine concentration in the outflow solution at the lower end of the plot was reduced by $25 \%$, while the concentration of picloram, a more soluble herbicide, was reduced by only $5 \%$.

The calculated mass balance in the soil profile indicates significant retention through mixture storage in the soil. Average mass reductions (Table 5) were $36.1 \%$ for atrazine and $20 \%$ picloram. For picloram, most of this was probably due to temporary soil storage.

The O horizon removal reduced the SMZ efficiency in trapping atrazine (Table 6). The percentage of trapped water was not dependent on the O horizon condition. Koppel et al. (1997) reported that the water retention in grass strips plots with $8 \%$ of slope varied as a function of the local and temporal variability of infiltration conditions. There was no difference in picloram-trapped concentration while atrazine was higher at plots where the 


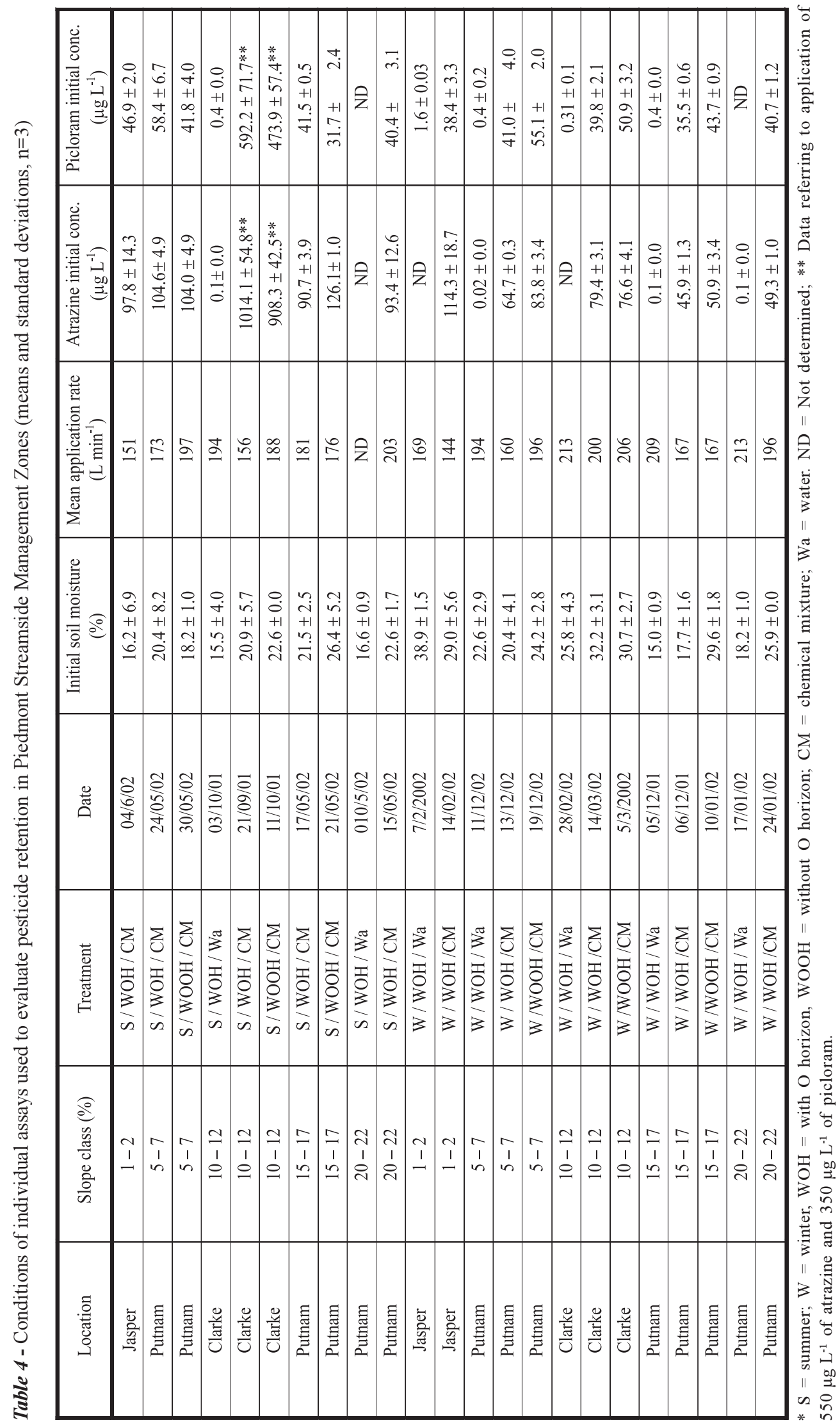


Table 5 - Concentration and mass reduction percentage of atrazine and picloram for simulation runs

\begin{tabular}{|c|c|c|c|c|c|c|c|}
\hline \multirow[b]{2}{*}{ Locality } & \multirow[b]{2}{*}{$\begin{array}{c}\text { Slope } \\
(\%)\end{array}$} & \multirow[b]{2}{*}{ Treatment* } & \multirow[b]{2}{*}{ Date } & \multicolumn{2}{|c|}{ Atrazine } & \multicolumn{2}{|c|}{ Picloram } \\
\hline & & & & $\begin{array}{l}\text { Concentration } \\
\text { reduction } \\
(\%)\end{array}$ & $\begin{array}{c}\text { Mass } \\
\text { reduction } \\
(\%)\end{array}$ & $\begin{array}{l}\text { Concentration } \\
\text { reduction } \\
(\%)\end{array}$ & $\begin{array}{c}\text { Mass } \\
\text { Reduction } \\
(\%)\end{array}$ \\
\hline Jasper & $1-2$ & $\mathrm{~S} / \mathrm{WOH}$ & $04 / 06 / 02$ & 2.0 & 16.2 & 1.4 & 15.7 \\
\hline Putnam & $5-7$ & $\mathrm{~S} / \mathrm{WOH}$ & $24 / 05 / 02$ & -3.0 & 19.7 & 5.6 & 26.4 \\
\hline Putnam & $5-7$ & S / WOOH & $30 / 05 / 02$ & 14.7 & 24.9 & -0.7 & 11.3 \\
\hline Clarke & $10-12$ & $\mathrm{~S} / \mathrm{WOH}$ & $21 / 09 / 01$ & 8.1 & 19.5 & 3.4 & 15.4 \\
\hline Clarke & $10-12$ & $\mathrm{~S} / \mathrm{WOOH}$ & $11 / 10 / 01$ & -1.4 & 21.2 & 8.7 & 29.0 \\
\hline Putnam & $15-17$ & $\mathrm{~S} / \mathrm{WOH}$ & $17 / 05 / 02$ & 80.7 & 83.9 & 39.3 & 49.6 \\
\hline Putnam & $15-17$ & $\mathrm{~S} / \mathrm{WOOH}$ & $21 / 05 / 02$ & 24.1 & 33.2 & 1.5 & 13.3 \\
\hline Putnam & $20-22$ & S / WOH & $15 / 05 / 02$ & 47.4 & 54.3 & 2.3 & 15.1 \\
\hline Jasper & $1-2$ & $\mathrm{~W} / \mathrm{WOH}$ & $14 / 02 / 02$ & 4.5 & 13.0 & -1.2 & 7.8 \\
\hline Putnam & $5-7$ & $\mathrm{~W} / \mathrm{WOH}$ & $13 / 12 / 02$ & 5.5 & 29.9 & -17.8 & 12.6 \\
\hline Putnam & $5-7$ & $\mathrm{~W} / \mathrm{WOOH}$ & $19 / 12 / 02$ & 17.0 & 26.8 & 6.6 & 17.6 \\
\hline Clarke & $10-12$ & $\mathrm{~W} / \mathrm{WOH}$ & $14 / 03 / 02$ & 43.7 & 48.5 & 11.7 & 19.3 \\
\hline Clarke & $10-12$ & $\mathrm{~W} / \mathrm{WOOH}$ & $05 / 03 / 02$ & 14.4 & 21.7 & 10.0 & 17.7 \\
\hline Putnam & $15-17$ & $\mathrm{~W} / \mathrm{WOH}$ & $06 / 12 / 01$ & 30.7 & 48.0 & 12.4 & 34.3 \\
\hline Putnam & $15-17$ & $\mathrm{~W} / \mathrm{WOOH}$ & $10 / 01 / 02$ & 47.2 & 59.0 & 13.6 & 32.8 \\
\hline Putnam & $20-22$ & W / WOH & $24 / 01 / 02$ & 50.3 & 57.7 & -12.9 & 3.9 \\
\hline & & & Overall & 24.1 & 36.1 & 5.2 & 20.1 \\
\hline & & & $\mathrm{SD}$ & 23.8 & 20.1 & 12.5 & 11.6 \\
\hline
\end{tabular}

* $\mathrm{S}=$ summer; $\mathrm{W}=$ winter, $\mathrm{WOH}=$ with $\mathrm{O}$ horizon, $\mathrm{WOOH}=$ without $\mathrm{O}$ horizon.

Table 6 - Trapping efficiency of atrazine and picloram, surface flow velocity, and trapped water on plots with and without O horizon

\begin{tabular}{|l|c|c|c|c|}
\hline \multicolumn{1}{|c|}{ Treatment } & $\begin{array}{c}\text { Atrazine } \\
(\%)\end{array}$ & $\begin{array}{c}\text { Picloram } \\
(\%)\end{array}$ & $\begin{array}{c}\text { Surface flow velocity } \\
\left(\mathrm{m} . \mathrm{min}^{-1}\right)\end{array}$ & $\begin{array}{c}\text { Trapped water } \\
(\%)\end{array}$ \\
\hline & Mean $\pm \mathrm{sd}^{*}$ & Mean $\pm \mathrm{sd}^{*}$ & Mean $\pm \mathrm{sd}^{*}$ & $\mathrm{Mean}^{*} \mathrm{sd}^{*}$ \\
\hline With O horizon & $27.0 \pm 28.0$ & $4.1 \pm 15.6$ & $4.7 \pm 2.2$ & $16.2 \pm 6.2$ \\
\hline Without O horizon & $19.4 \pm 16.0$ & $5.5 \pm 6.0$ & $20.4 \pm 4.6$ & $14.8 \pm 5.9$ \\
\hline
\end{tabular}

* sd: Standard deviation.

O horizon was kept undisturbed. Even though, the initial concentration of atrazine and picloram within plots without $\mathrm{O}$ horizon were, respectively, 13.7 and $3.5 \%$ lower than in the plots with O horizon (Table 4). The absence of O horizon resulted in an increase of almost 5 times the surface flow velocity, indicating that the presence of $O$ horizon can improve the infiltration of the mixture. However, the amount of surface flow retained was not significantly higher at the plots with $\mathrm{O}$ horizon.

Correlation of herbicide retention and selected site factors are presented in Table 7 for all simulation runs and in Table 8 for simulation runs with only undisturbed $O$ horizon plots. Atrazine and picloram attenuation tended to be correlated with one another. The correlation between picloram and atrazine concentration was relatively strong across all simulation runs but less so when only undisturbed $\mathrm{O}$ horizon simulation runs were included in the analysis. In contrast, velocity and slope were correlated when the confounding effects of $O$ horizon removal were eliminated from the analysis (Table 8). Surprisingly, both surface flow velocity and slope were positively correlated with atrazine 
Table 7 - Pearson correlation among slope velocity, atrazine, picloram and kaolin attenuation in concentration, using data from all sites

\begin{tabular}{|c|c|c|c|c|c|}
\hline & $\begin{array}{c}\text { Atrazine } \\
\text { attenuation }\end{array}$ & $\begin{array}{c}\text { Picloram } \\
\text { attenuation }\end{array}$ & Slope & $\begin{array}{l}\text { Antecedent soil } \\
\text { moisture }\end{array}$ & $\begin{array}{c}\text { Surface flow } \\
\text { velocity }\end{array}$ \\
\hline Atrazine attenuation & 1.0 & $\begin{array}{c}0.79 \\
\mathrm{p}<0.01\end{array}$ & $\begin{array}{c}0.52 \\
p=0.04\end{array}$ & $\begin{array}{c}0.18 \\
\mathrm{p}=0.51\end{array}$ & $\begin{array}{c}0.18 \\
\mathrm{p}=0.51\end{array}$ \\
\hline Picloram attenuation & $\begin{array}{c}0.79 \\
p<0.01\end{array}$ & 1.00 & $\begin{array}{c}0.31 \\
\mathrm{p}=0.25\end{array}$ & $\begin{array}{c}0.11 \\
p=0.69\end{array}$ & $\begin{array}{c}0.20 \\
p=0.46\end{array}$ \\
\hline Slope & $\begin{array}{c}0.52 \\
p=0.04\end{array}$ & $\begin{array}{c}0.31 \\
\mathrm{p}=0.25\end{array}$ & 1.00 & $\begin{array}{c}0.16 \\
p=0.55\end{array}$ & $\begin{array}{c}0.16 \\
p=0.57\end{array}$ \\
\hline Antecedent soil moisture & $\begin{array}{c}0.18 \\
p=0.50\end{array}$ & $\begin{array}{c}0.11 \\
p=0.69\end{array}$ & $\begin{array}{c}0.16 \\
p=0.55\end{array}$ & 1.00 & $\begin{array}{c}-0.26 \\
p=0.33\end{array}$ \\
\hline Surface flow velocity & $\begin{array}{c}0.18 \\
\mathrm{p}=0.51\end{array}$ & $\begin{array}{c}0.20 \\
\mathrm{p}=0.46\end{array}$ & $\begin{array}{c}0.16 \\
p=0.57\end{array}$ & $\begin{array}{c}-0.26 \\
p=0.33\end{array}$ & 1.00 \\
\hline
\end{tabular}

P: Probability.

Table 8 - Pearson correlation among slope velocity, atrazine, picloram and kaolin attenuation in concentration, using data from undisturbed $\mathrm{O}$ horizon sites

\begin{tabular}{|l|c|c|c|c|c|}
\hline & $\begin{array}{c}\text { Atrazine } \\
\text { attenuation }\end{array}$ & $\begin{array}{c}\text { Picloram } \\
\text { attenuation }\end{array}$ & Slope & $\begin{array}{c}\text { Antecedent } \\
\text { soil moisture }\end{array}$ & $\begin{array}{c}\text { Surface flow } \\
\text { velocity }\end{array}$ \\
\hline Atrazine attenuation & 1.00 & $\begin{array}{c}0.39 \\
\mathrm{p}=0.26\end{array}$ & $\begin{array}{c}0.51 \\
\mathrm{p}=0.13\end{array}$ & $\begin{array}{c}0.13 \\
\mathrm{p}=0.72\end{array}$ & $\begin{array}{c}0.49 \\
\mathrm{p}=0.15\end{array}$ \\
\hline Picloram attenuation & $\begin{array}{c}0.39 \\
\mathrm{p}=0.26\end{array}$ & 1.00 & $\begin{array}{c}0.16 \\
\mathrm{p}=0.67\end{array}$ & $\begin{array}{c}0.35 \\
\mathrm{p}=0.32\end{array}$ & $\begin{array}{c}-0.18 \\
\mathrm{p}=0.63\end{array}$ \\
\hline Slope & $\begin{array}{c}0.51 \\
\mathrm{p}=0.13\end{array}$ & $\begin{array}{c}0.16 \\
\mathrm{p}=0.67\end{array}$ & 1.00 & $\begin{array}{c}0.19 \\
\mathrm{p}=0.62\end{array}$ & $\begin{array}{c}0.66 \\
\mathrm{p}=0.04\end{array}$ \\
\hline Antecedent soil moisture & $\begin{array}{c}0.13 \\
\mathrm{p}=0.72\end{array}$ & $\begin{array}{c}0.35 \\
\mathrm{p}=0.32\end{array}$ & $\begin{array}{c}0.19 \\
\mathrm{p}=0.62\end{array}$ & $\begin{array}{c}1.00 \\
\mathrm{p}=0.56\end{array}$ \\
\hline Surface flow velocity & $\begin{array}{c}0.49 \\
\mathrm{p}=0.15\end{array}$ & $\begin{array}{c}-0.18 \\
\mathrm{p}=0.63\end{array}$ & $\begin{array}{c}0.66 \\
\mathrm{p}=0.04\end{array}$ & $\begin{array}{c}-0.21 \\
\mathrm{p}=0.56\end{array}$ & 1.00 \\
\hline
\end{tabular}

attenuation suggesting that greater velocities and slope increased retention.

A wide range in retention of atrazine in grassed filter strips has been reported, from 11 to $100 \%$ (Arora et al., 1996). In these grass filter strips, the variability in retention was due largely to variability among events in amount of infiltration. Similarly, Vellidis et al. (2002) reported an average reduction of $88 \%$ of atrazine concentration in natural precipitation induced runoff in riparian buffer systems. In contrast with these results, in the large surface flow events simulated in this experiment, infiltration was less important than in these previous studies.
Natural channels on the soil surface induce concentrated flow, facilitating chemical mobility (Reungsang et al., 2001) and therefore, reduce herbicide retention. An example is provided by Dillaha et al.(1989), who found that grass filter strips seem to be ineffective on steeper hill slope due to concentrated flow conditions.

Higher flow velocities occurred on steep slopes in these experiments suggesting that measured reductions in concentration would be relatively low. Along the $20 \%$ slope plot, the average surface flow velocity was $9.6 \pm$ $8.4 \mathrm{~m} \mathrm{~min}^{-1}$ while the average for other plots (slope ranging from 2 to $15 \%$ ) was $2.7 \pm$ 
$1.6 \mathrm{~m} \mathrm{~min}^{-1}$. Despite this, a correlation between slope and herbicide reduction was not observed, although a positive correlation $(\mathrm{p}>0.037)$ was obtained for slope and surface flow velocity.

The calculated load retention was higher than the obtained for concentration. According to McCutcheon et al. (2000), when the balance is based on mass, the calculations do not reflect the effects of changes in water volume. On the other hand, the dimensionless trapped concentration suggested by Kelly (1995), normalizes the mass balance with respect to the amount of surface flow retained, infiltration, evaporated or transpired on a vegetative filter strip, buffer, or other best management practice. Trapping efficiency average of atrazine in all plots with $\mathrm{O}$ horizon was 24.1 while picloram was 4.6. The lower trapping efficiency obtained for picloram (more soluble) corroborates a more efficient trapping through mixture infiltration in soil.

Besides infiltration, $O$ horizon can enhance herbicide retention through adsorption to litter and soil particles present in the $\mathrm{O}$ horizon. In a companion study, results showed that, after 30 seconds and 10 minutes, adsorption to $O$ horizon samples reduced atrazine concentration by $5 \%$ and $15 \%$, respectively. Picloram was not adsorbed to the O horizon.

By using simulated rainfall on $24.4 \mathrm{~m}$ long waterways, Asmussen et al. (1977) found that total losses of 2,4-D were 2.5 and $10.3 \%$ for dry and wet plots, respectively. Rhode et al. (1980) found higher herbicide reduction in buffer strips during dry soil conditions. The correlation between the initial soil moisture and water retained on the plot occurred, but was low $(r=0.46)$, apparently due to differences in soil conditions.

There was no correlation between initial soil moisture and surface flow velocity $(\mathrm{r}=$ 0.17); initial soil moisture, slope and $O$ horizon conditions were the overriding factors. As the relationship between initial soil moisture and trapped water was poor, and no relationship between initial soil moisture and surface flow velocity existed, the poor relationship between initial soil moisture and herbicide retention $(\mathrm{r}=0.46$ and 0.26 , respectively) was not surprising.
Different factors apparently control herbicide retention in forested SMZs. One possible factor not relevant to grassed filter strips is $\mathrm{O}$ horizon development. Although relatively few individual sites were evaluated in this project, relatively strong relationships existed between $O$ horizon depth and herbicide retention for undisturbed plots (Figure 2). Addition of raked plots to the relationship still produces a significant relationship, but it is not as strong.

The obtained results showed that slope and initial soil moisture, two factors previously reported to be good predictors of herbicide retention, were relatively unimportant in this study. Instead, O horizon appeared to be the most important factor affecting herbicide retention. O horizon removal reduced herbicide removal efficiency and increases overland flow velocity, elevating the risk of aquatic contamination. In undisturbed plots, retention was related to O horizon depth. Where SMZs are steeply sloping, the O horizon must be left undisturbed for SMZs to be effective.

For atrazine or herbicides with even higher soil sorption (e. g. glyphosate), these herbicides are probably effectively prevented from reaching surface water. The permanency of picloram retention would depend on the rate of seepage of stored soil water to surface water and the half-life of picloram in soil.

Although $10 \mathrm{~m}$ long SMZs are not completely efficient in retaining herbicide, these data suggest that increased retention would occur in wider SMZ strips. Particularly for atrazine and similarly sorbed herbicides, and even on steep slopes, a $10 \mathrm{~m}$ wide SMZ provides significant protection surface water protection. The trapping efficiency of herbicides tends to increase with the buffer zone length. Koppel et al. (1997) found higher reduction (more than $90 \%$ ) on a $15 \mathrm{~m}$ long strip in relation to a $10 \mathrm{~m}$ long one $(80 \%)$. Our result indicates lower herbicide reduction in $10 \mathrm{~m}$ but, according to Misra et al. (1996), efficient atrazine trapping requires $20.1 \mathrm{~m}$ long buffer strips, and it does not have to be vegetated. Reduction percentages of atrazine in riparian forest buffer system higher than $80 \%$ were found elsewhere (Lowrance et al., 1997; Vellidis et al., 2002), but the length was almost $40 \mathrm{~m}$. 


\section{ACKNOWLEDGEMENTS}

We would like to express our appreciation to CAPES/Brazil and the Environmental Protection Agency/US for funding this research.

\section{LITERATURE CITED}

ALLRAN, J. W.; KARASOV, W. H. Effects of atrazine on embryos, larvae, and adults of anuran amphibians. Environ. Toxicol. Chem., v. 20, n. 4, p. 769-775, 2001.

AORA, K. et al. Herbicide retention by vegetative buffer strips from runoff under natural rainfall. Trans. Soc. Agric. Eng, v. 39, n. 6, p. 2155-2162, 1996.

ASMUSSEN, L. E. et al. Reduction of 2,4-D load in surface runoff down a grassed waterway. J. Environ. Quality, v. 6, n. 1, p. 159-162, 1977.

DALTON, R. Frogs put in the gender blender by America's favourite herbicide. Nature, v. 416, n. 6882, p. 665-666, 2002 .

DILLAHA, T. A.; RENUEAU, S. M.; LEE, D. Vegetative filter strips for agricultural non point source pollution control. Trans. Am. Soc. Agric. Eng., v. 32, n. 2, p. 513$519,1989$.

FRANKLIN, D. H. et al. Evaluation of percent flow captured by a small in-field runoff collector. Trans. Am. Soc. Agric. Eng., v. 44, n. 3, p. 551 - 554, 2001.

HAYES, T. B. et al. Hermaphroditic, demasculinized frogs after exposure to the herbicide atrazine at low ecologically relevant doses. Proc. National Acad. Sci., v. 99, n. 8, p. 5476-5480, 2002.

KELLY, M. Trapping of storm water ponds and review of other best management practices for water control. 1995. 75 f. (MS Thesis) - Clemson University, Clemson, 1995.

KOPPEL, H.; KORDEL, W.; STEIN, B. Herbicide transport by surface runoff and herbicide retention in a filter strip rainfall and runoff simulation studies. Chemosphere, v. 35, p. $129-141,1997$.

LOWRANCE, R. Riparian forest ecosystems as filters for non point-source pollution. In: PACE, M. L.; GROFFMAN, P. M. Limitations and frontiers in ecosystem science. New York: Springer, 1998. p. 113-141.

LOWRANCE, R. et al. Herbicide transport in a managed riparian forest buffer system. Trans. Am. Soc. Agric. Eng., v. 40, n. 4, p. 1047-1057, 1997.

Planta Daninha, Viçosa-MG, v. 26, n. 1, p. 131-142, 2008
MCCUTCHEON, S. C. et al. Evaluation of vegetative filter strips to control urban runoff into Charleston harbor and other coastal waters. Clemson: Clemson University, 2000. v. 1, 248 p. (EPA Report)

MERSIE, W. et al. Effectiveness of switchgrass filter strips in removing dissolved atrazine and metolachlor from runoff. J. Environ. Quality, v. 28, n. 3, p. 816-821, 1999.

MISRA, A.K. et al. H. Contributing area and concentration effects on herbicide removal by vegetative buffer strips. Trans. Am. Soc. Agric. Eng., v. 39, n. 6, p. 2105-2111, 1996.

NCASI. The effectiveness of buffer strips for ameliorating offsite transport of sediment, nutrients, and pesticides from silvicultural operations. New York: 1992. (Technical Bulletin, 631).

NOBORIO, K. Measurement of soil and water content and electrical conductivity by time domain reflectrometry: A review. Comp. Electron. Agric., v. 31, p. 213-237, 2001.

PATERSON, K. G.; SCHOONOR, J. L. Fate of allachlor and atrazine in a riparian zone field site. Water Environ. Res., v. 64, p. 274-283, 1992.

REUNGSANG, A.; MOORMAN, T. B.; KANWAR, R. S. Transport and fate of atrazine in midwestern riparian buffer strips. J. Am. Water Res. Assoc., v. 37, n. 6, p. 1681-1692, 2001.

RHODE, W. A. et al. Trifuralin movement in runoff from a small agricultural watershed. J. Environ. Quality, v. 9, n. 2, p. $37-42,1980$.

RIVENBARK, L. Headwater stream management issues in Georgia: streamside management zone effectiveness and small trout stream hydrologic characterization. 2002. 83 f. (MS Thesis) - University of Georgia, Athens, 2002.

VELLIDIS, G.; LOWRANCE, R.; SMITH, M. C. A quantitative approach for measuring $\mathrm{N}$ and $\mathrm{P}$ concentration changes in surface runoff from a restored riparian forest wetland. Wetlands, v. 14, p. 73-81, 1994.

VELLIDIS, G. et al. Herbicide transport in restored riparian forest buffer system. Trans. Am. Soc. Agric. Eng., v. 45, n. 1, p. 89-97, 2002.

WARD, J. M. Sediment trapping within streamside management zones on two clearcut sites in the Georgia Piedmont. 2001. 85 f. (MS Thesis) - University of Georgia, Athens, 2001.

WEBSTER, E. P.; SHAW, D. Impact of vegetative filter strips on herbicide loss in runoff from soybean (Glycine max). Weed Sci., v. 44, n. 3, p. 662-671, 1996. 